\title{
Growth control of herbaceous ground cover and egg quality from an integrated poultry-hazelnut orchard system
}

\author{
Carlo Cosentino, Pierangelo Freschi, Simonetta Fascetti, Rosanna Paolino, Mauro Musto \\ School of Agricultural, Forestry, Food and Environmental Sciences, University of Basilicata, Potenza, Italy
}

\begin{abstract}
The present study was designed to assess the impact of hen grazing on plant biodiversity in the ground cover of hazelnut orchards, as well as the quality of eggs from hens grazing in the orchards. Two different sites of hazelnut orchards located in Basilicata region were selected to conduct this study. The results showed that hen grazing affected the composition of herbaceous stratum of the orchards. By using the quadrat method, a total of 99 (46 in site A and 53 in site B) plant species were identified at the beginning of the trial. After hen grazing, the number of identified plants dropped to 72 (30 in site A and 42 in site B). Amongst the most consumed species we found Lolium sp., Trifolium sp., Polygonum sp., Cichorium intybus, Cynodon dactylon. Alpha diversity analysis (species richness, diversity and evenness) as well as beta diversity analysis (Morisita-Horn and Sørensen indices) confirmed that hen grazing played a role in controlling vegetation growth. Concerning egg quality, most of the chemical parameters differed significantly when comparing the eggs from the sites with those from the control group, indicating that egg quality was influenced by the food resources available in each site. Overall, our results confirm that poultry may play a positive role in an orchard system.
\end{abstract}

Correspondence: Carlo Cosentino, School of Agricultural, Forestry, Food and Environmental Sciences, University of Basilicata, viale dell'Ateneo Lucano 10, 85100 Potenza, Italy.

Tel.: +39.0971205044.

E-mail: carlo.cosentino@unibas.it

Key words: Biodiversity; egg quality; grazing; orchard; poultry.

Acknowledgements: the study presented in this paper has been funded by the Basilicata Region in the framework of the Rural Development Programme 2014-2020, Measure 16 - Cooperation, Sub-measure 16.1 - Support for the establishment and management of agricultural productivity and sustainability operational groups objectives - Project 'CORILUS - Sustainable Lucanian Coriliculture'. The authors deeply appreciate and thank the collaboration from the Rete di Imprese 'Basilicata in Guscio' and its associated farms.

Received for publication: 27 January 2020.

Revision received: 6 May 2020.

Accepted for publication: 6 May 2020.

(C) Copyright: the Author(s), 2020

Licensee PAGEPress, Italy

Italian Journal of Agronomy 2020; 15:1594

doi:10.4081/ija.2020.1594

This article is distributed under the terms of the Creative Commons Attribution Noncommercial License (by-nc 4.0) which permits any noncommercial use, distribution, and reproduction in any medium, provided the original author(s) and source are credited.

\section{Introduction}

In recent years, after restricting and, in some cases, banning the use of conventional intensive systems, there has been a renewed interest in pasture-based systems and pasture-raised livestock products. This is particularly true for poultry, since the use of pasture-based systems for poultry production is growing due to consumer demand for speciality natural and welfare-friendly meat and eggs (Antell and Ciszuk, 2006; Anderson, 2011; Sossidou et al., 2011; Chielo et al., 2016). These concerns have led to a considerable amount of research on comparing conventional raising systems with range raising systems, as well as on the effects of each system on egg quality (Krawczyk, 2009, 2011; Matt et al., 2009; Karsten et al., 2010; Anderson, 2011; Holt et al., 2011; Küçükyılmaz et al., 2012; Rizzi and Marangon, 2012). Other studies have focused on forage consumption of laying hens on free range (Antell and Ciszuk, 2006; Horsted et al., 2007; Singh and Cowieson, 2013; Skřivan et al., 2015). Lolium sp., Trifolium sp., Polygonum sp., Cichorium intybus, Cynodon dactylon were found to be, amongst others, the most occurring plant species in grazing hens' diet (Horsted et al., 2006; Mugnai et al., 2009; Liu et al., 2011; Skřrivan et al., 2015; Meng et al., 2016; Sirri et al., 2018; Zheng et al., 2019).

Free-range system is a recognizing animal welfare friendly method, as it provides birds with sunlight, fresh air, ample space, nutrients, etc., as well as allows them to express natural behaviours (Berg, 2002; Sossidou et al., 2011; Mohammed et al., 2013). Moreover, raising poultry on free-range offers many advantages in terms of farm soil fertility, disease prevention, weed control, farm diversity, environmental sustainability, farm profitability, etc. (Glatz et al., 2005; Sossidou et al., 2011; Liu et al., 2013).

An interesting approach is to integrate hen grazing within high value fruit trees systems (e.g., olive, hazelnut, walnut, almond, chestnut, apple, and pear systems) in order to obtain an additional source of income while providing weed control and fertilisation, thus lowering costs and impact of the management. Previously published studies on the association between hen grazing and orchards (Clark and Gage, 1996; Lavigne et al., 2012; Paolotti et al., 2016; Rosati et al., 2016; Timmermans, 2016) have only focused on fruit quality, weed and pest control, sustainability. In contrast, there is much less information about the effects of an integrated poultry-orchard system on herbaceous plant species diversity or egg quality. Therefore, the present study was designed to investigate: i) the impact of hen grazing integrated into hazelnut orchards on plant biodiversity in the ground cover; ii) the quality of eggs from hens grazing in the orchards. 


\section{Materials and methods}

\section{Study sites}

The present study - which is part of a project called 'CORILUS - Sustainable Lucanian Coriliculture' whose objective is to improve the hazelnut production in Basilicata region (south of Italy) - is a first attempt to analyse an integrated poultry-hazelnut orchard system. Within the aforementioned project, two pilot farms were selected according the following criteria: i) farm location (Province of Potenza); ii) age of the trees (three years); iii) unproductive condition (trees require roughly 4 years to mature before they are able to provide hazelnuts); iv) cultivar (Corylus avellana, 'Tonda di Giffoni'); v) tree spacing $(3 \times 5 \mathrm{~m})$.

The study was conducted from May 2019 to September 2019 in two different sites, one for each selected farm. The first site (site A; $40^{\circ} 49^{\prime} 57.62$ ' $\mathrm{N}-15^{\circ} 42^{\prime} 44.42$ ' E) has an area of approximately 4 ha and lies within 500 to $550 \mathrm{~m}$ a.s.l.; its mean annual precipitation is $730 \mathrm{~mm}$, whereas its mean annual air temperature is $+12^{\circ} \mathrm{C}$. The hazelnut trees are here planted in a medium-textured soil tending to sandy (sand: $65.10 \%$; clay: $21.50 \%$; silt: $13.40 \%$ ).

In the second site (site B; 40²4'16.76' N - 1543'44.80'), which spans approximately 5 ha, the elevation is 660 ha $\mathrm{m}$ a.s.l., the mean annual precipitation and the mean annual air temperature are $780 \mathrm{~mm}$ and $13^{\circ} \mathrm{C}$, respectively. A loamy textured soil (sand: $48.40 \%$; clay: $23.20 \%$; silt: $28.40 \%$ ) was found in this site.

\section{Animals, housing and feeding}

A total of 90 hens belonging to a commercial egg-laying genotype were purchased from a local poultry firm. At 25-weeks of age, the hens were randomly divided into three homogeneous groups of 30 birds each. Hens from group A and B were assigned to site A and B, respectively. Hens composing the third group (control group) were kept at the local poultry firm under free-range farming condition $\left(2 \mathrm{~m}^{2} /\right.$ bird $)$.

Each site was divided into 3 homogeneous areas, each provided with a mobile coop to confine the hens $\left(5 \mathrm{birds} / \mathrm{m}^{2}\right)$ for protection from predators during the night and to encourage egglaying in coop nests. Feed and water were provided outside each mobile coop with feeders and automatic drinkers, respectively. All hen groups were fed on the same basal diet, a commercial feed with the following characteristics: crude protein $17 \%$, crude fat $4.50 \%$, crude fibre $4.50 \%$, crude ash $13 \%$, lysine $0.90 \%$, methionine $0.36 \%$, Ca $4 \%, \mathrm{P}$ $0.56 \%$, Na 0.17\%, vitamin A 6000 IU, vitamin D3 1800 IU. Besides, the hens from both site groups were given access to the pasture for 12 hours a day (from 07:00 a.m. to 07:00 p.m.), with drinking water being available on an libitum basis.

\section{Ground cover composition assessment}

The botanical composition of the herbaceous stratum of each site was evaluated before (first decade of May) and after hen grazing (first decade of September) by using the quadrat method (Bonham, 1989) modified by Rizzardini et al. (2019). Briefly, in each site 320 $\mathrm{m}$ transects were used to sample vegetation. Along each transect, separated from one another by $1 \mathrm{~m}$, plant species were listed in 20 quadrats (sized $1 \mathrm{~m}^{2}$ ) arranged at a distance of $1 \mathrm{~m}$ from each other. The collected specimens were identified according to Flora d'Italia (Pignatti et al., 2019) and follow the taxonomic nomenclature of this text.

\section{Chemical composition of eggs}

In each site, eggs were daily gathered during the whole experimental period. For chemical analysis, 11 eggs were randomly selected in each site from each mobile coop on the last 3 days of the experimental period. Following Karsten et al. (2010), 3 eggs were randomly selected from the collected 11 eggs, and the egg yolks were pooled. A total of 3 pooled-yolk samples per group ( 9 yolks total) were used to evaluate the following parameters: dry matter by oven drying the sample at $100^{\circ} \mathrm{C}$ for $18 \mathrm{~h}$; total lipids (Folch et al., 1957); protein and ash (AOAC, 2006); cholesterol (Meluzzi et al., 1993); vitamin A, D and E (Karsten et al., 2010); fatty (monounsaturated, polyunsaturated, and saturated) acids (Matt et al., 2009); lysozyme (Labella et al., 2016).

\section{Statistical analysis}

For each site, data on the identified species before and after hen grazing were used to calculate the relative percentage $(r p)$ of a taxon composing the ground cover (Freschi et al., 2014, 2015a, 2016, 2017):

$$
r p=(n / N) \times 100
$$

where: $n$ is the number of occurrences attributed to a given taxon in a given period of the trial (before or after hen grazing); $N$ is the total number of identified occurrences in that given period. The MannWhitney $U$-test was used to compare the changes in vegetation composition between the two sampling periods; the statistical significance was set at $\mathrm{P}<0.05$.

Alpha diversity analysis was computed in each site by using the following indices: i) species richness $(D)$, for which the higher the value the greater the richness (Margalef, 1958); ii) species diversity $(H)$ (Shannon and Weaver, 1949), whose value usually ranges between 1.5 and 3.5 and often does not exceed 4 (Margalef, 1972); and iii) species evenness (E) (Buzas and Gibson, 1969), whose value ranges between 0 and 1 , where 1 indicates that all the food items are used to an equal extent. Differences in richness, diversity, and evenness calculated before and after hen grazing were analysed by the Student $t$-test.

Two beta diversity indices were used in each site in order to measure the extent of differentiation in species composition between the two sampling periods: i) the quantitative Morisita-Horn index $\left(C_{M H}\right)$ (Morisita, 1959), which takes into account the species present in each sample and their abundance (Magurran, 2004); and ii) the qualitative Sørensen index $\left(C_{S}\right)$ (Sørensen, 1948), which only considers presence/absence data. Typically, the value of these indices ranges from 0 (complete dissimilarity between sites) to 1 (complete similarity between sites). $C_{M H}$ values were classified according to the scale proposed by Langton (1982): $0<C_{M H} \leq 29$, small overlap; $30 \leq C_{M H} \leq 59$, medium overlap; and $C_{M H} \geq 60$, high overlap.

In each site, the Student $t$-test was used to determine the significance of the differences in chemical composition of eggs from experimental group and those from control group.

\section{Results and discussion}

\section{Composition of the cover vegetation on the ground}

A total of forty-six plant species were identified in the herbaceous stratum of site $\mathrm{A}$ at the beginning of the trial (Table 1). Almost half of the taxa (46\%) were observed in low percentages $(<1 \%)$; among them, there were Daucus carota, Picris hieracioides, Malva sylvestris, Trifolium campestre, etc. Other taxa were instead 
observed at higher percentages: for instance, the following ten taxa accounted for $57.63 \%$ of the all observed species composing the herbaceous stratum: Anthemis arvensis (7.93\%), Lolium perenne (7.52\%), Avena sterilis (6.89\%), Phalaris minor (6.47\%), Cirsium creticum triumfettii (6.05\%), Rumex crispus (5.64\%), Lysimachia arvensis (5.43\%), Trifolium alexandrinum (4.18\%), C. intybus $(3.76 \%)$ and Vicia sativa (3.76\%). Concerning the Site B, the first vegetation sampling allowed to identify fifty-three plant taxa composing the herbaceous stratum (Table 2), with relative percentages ranging from 0.27 to $12.80 \%$. More than half $(50.40 \%)$ of the identified species was represented by the eight following taxa: Helminthotheca echioides (12.8\%), P. hieracioides (10.4), Senecio vulgaris (5.87), Sonchus oleraceus (5.87), Equisetum arvense (4.27), Medicago truncatula (3.73), Poa pratense (3.73), T. repens (3.73).

The composition of herbaceous vegetation, along with other farm characteristics (rainfall, temperature, altitude, etc.), are key elements differentiating the two study sites. The presence of some taxa (e.g., C. dactylon, D. carota, L. perenne, P. hieracioides) in the ground cover of the sites has been also recorded in some seminatural landscapes of Basilicata region (Freschi et al., 2015a, $2015 b$ ). Moreover, among the taxa observed in the present study, there were some species (e.g., Lolium spp., Trifolium spp., D. carota, Convolvulus arvensis, etc.) identified as components of the pasture available for organic Ancona laying hens, as well as of their diet (Mugnai et al., 2009).

After hen grazing, thirty taxa were observed in the site A, with a relative percentage ranging from 0.33 to $9.51 \%$ (Table 1 ). The most observed taxa were Anthemis arvensis (9.51\%), A. sterilis (9.51\%), C. intybus (8.52\%), C. creticum ssp. triumfettii $(8.20 \%)$, L. perenne $(8.20 \%)$, Polygonum aviculare $(7.87 \%)$; altogether, these six taxa accounted for $51.81 \%$ of the all observed species. The plant species observed in site B at the end of the trial were fortytwo (Table 2), with seven of them accounting for more than half (54.54\%) of the total identified taxa: H. echioides (14.05\%), P. hieracioides (11.29\%), T. repens (6.34\%), Lactuca serriola (6.06\%), Verbena officinalis $(6.06 \%)$, E. arvense $(5.51 \%)$, L. arvensis $(5.23 \%)$. Previous studies have shown that, some of the plant species observed after hen grazing in both sites are particularly appetizing to hens (Horsted et al., 2006; Mugnai et al., 2009; Skřivan et al., 2015; Sirri et al., 2018): in particular, Horsted et al. (2006) found, by the use of microhistological analysis of faeces, that Lolium sp., Trifolium sp., Polygonum sp. were components of the diet of free-range laying hens. Other studies (Liu et al., 2011; Meng et al., 2016; Zheng et al., 2019) highlighted the importance of $C$. intybus as a beneficial feed ingredient for poultry.

Changes observed in the herbaceous stratum composition of site $A$ and $B$ between the two vegetation sampling periods are depicted in Figures 1 and 2, respectively.

The Mann-Whitney $U$ test revealed a significant difference $(\mathrm{P}<0.001)$ between the two vegetation sampling periods in site $\mathrm{A}$, thus indicating that the hens played an important role on controlling vegetation growth. This result is probably due to the fact that some taxa which were previously identified as components of the herbaceous stratum of the site, were less observed (e.g., C. arvensis, C. dactylon, M. truncatula, Papaver rhoeas, etc.) or no more observed (e.g., Elymus caninum, Beta vulgaris ssp. maritima, Calamintha nepeta ssp. nepeta, Lepidium draba, etc.) after hen grazing. For nineteen taxa, instead, there was an increase of their presence: the relative percentage of Amarantus retroflexus, $D$. carota, L. perenne, L. multiflorum, etc. was higher at the end than at beginning of the trial. With regard to site B (Figure 2), the difference observed between the sampling periods was not significant, although there was a decrease in the number (from 53 to 42) of some taxa (e.g., Vicia sp., Polygonum aviculare, P. annua, etc.), as well as a change in relative percentages of other taxa (e.g., T. repens, L. serriola, Mentha suaveolens, etc.).

Table 1. Relative percentage (\%) of plant species identified in Site $A$ before and after hen grazing.

\begin{tabular}{|c|c|c|}
\hline Species & Before grazing & After grazing \\
\hline Elymus caninum & 0.42 & 0.00 \\
\hline Amaranthus retroflexus & 0.84 & 0.98 \\
\hline Amni majus & 0.63 & 3.61 \\
\hline Lysimachia arvensis & 5.43 & 5.90 \\
\hline Anthemis arvensis & 7.93 & 9.51 \\
\hline Avena sterilis & 6.89 & 9.51 \\
\hline Beta vulgaris ssp. maritima & 2.71 & 0.00 \\
\hline Calamintha nepeta ssp.nepeta & 0.63 & 0.00 \\
\hline Lepidium draba & 0.84 & 0.00 \\
\hline Cichorium intybus & 3.76 & 8.52 \\
\hline Cirsium creticum ssp. triumfettii & 6.05 & 8.20 \\
\hline Convolvulus arvensis & 2.71 & 1.31 \\
\hline Cynodon dactilon & 2.51 & 1.31 \\
\hline Daucus carota & 0.42 & 0.66 \\
\hline Erigeron canadensis & 1.88 & 2.95 \\
\hline Geranium dissectum & 1.46 & 0.00 \\
\hline Polycarpon tetraphyllum ssp. diphyllum & 0.42 & 1.31 \\
\hline Kickxia elatine ssp. elatine & 1.46 & 3.93 \\
\hline Lactuca serriola & 0.63 & 0.00 \\
\hline Lathyrus pratensis & 0.42 & 0.00 \\
\hline Legousia speculum veneris & 0.42 & 0.66 \\
\hline Lolium multiflorum & 2.09 & 4.26 \\
\hline Lolium perenne & 7.52 & 8.20 \\
\hline Malva sylvestris & 0.21 & 0.00 \\
\hline Medicago lupulina & 1.25 & 0.00 \\
\hline Medicago truncatula & 0.63 & 0.33 \\
\hline Onobrychis viciifolia & 1.04 & 0.00 \\
\hline Onopordon acanthium & 0.84 & 0.98 \\
\hline Papaver rhoeas & 2.09 & 0.33 \\
\hline Phalaris minor & 6.47 & 2.95 \\
\hline Phleum nodosum & 2.51 & 0.00 \\
\hline Picris echioides & 2.30 & 3.28 \\
\hline Picris hieracioides & 0.42 & 0.66 \\
\hline Policarpon teraf. & 0.42 & 0.00 \\
\hline Polygonum aviculare & 2.92 & 7.87 \\
\hline Ranunculus bulbosus & 0.84 & 0.33 \\
\hline Rumex crispus & 5.64 & 5.57 \\
\hline Scabiosa maritima & 0.00 & 0.33 \\
\hline Scandix pecten veneris & 0.84 & 0.00 \\
\hline Setaria italica & 0.42 & 0.00 \\
\hline Sherardia arvensis & 0.21 & 0.00 \\
\hline Sisymbrium orientale & 3.13 & 0.33 \\
\hline Smirnum polisacrum & 0.21 & 0.00 \\
\hline Soncus arvensis & 1.46 & 1.31 \\
\hline Trifolium alessandrinum & 4.18 & 3.61 \\
\hline Trifolium campestre & 0.21 & 0.00 \\
\hline \multirow[t]{2}{*}{ Vicia sativa } & 3.76 & 1.31 \\
\hline & 100 & 100 \\
\hline
\end{tabular}




\section{Alpha and beta diversity analysis}

The results of alpha diversity analysis conducted in site A are shown in Table 3. The Student $t$-test revealed a significant difference in species richness and diversity between the two vegetation sampling periods. The value of Margalef's index $(D)$ was significantly higher before than after hen grazing (3.33 vs 2.75; $\mathrm{P}<0.001)$. Similarly, the value of the Shannon diversity index $(H)$ was maximum at the beginning of the trial (1.99 vs $1.73 ; \mathrm{P}<0.01)$.

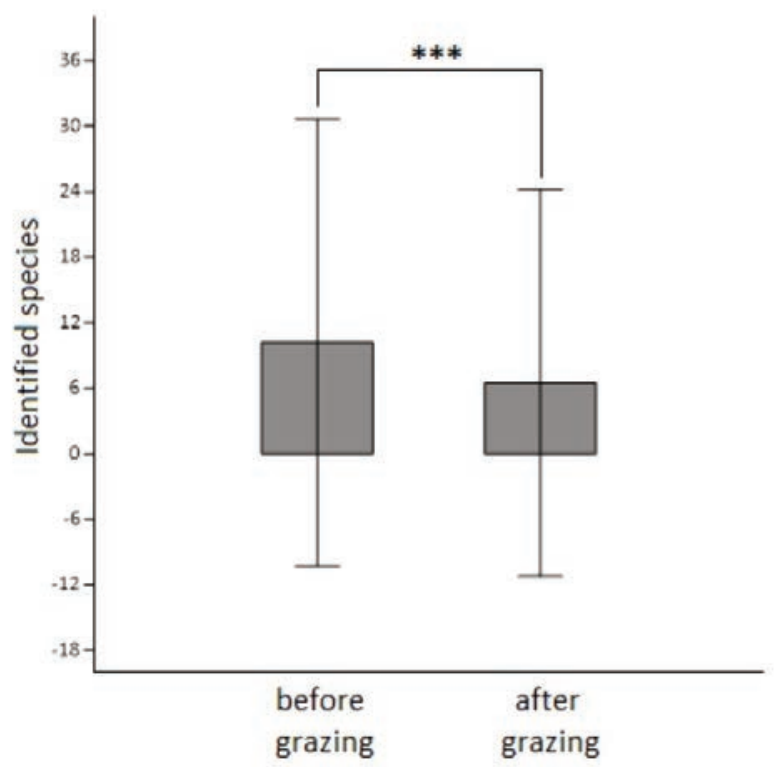

Figure 1. Changes in vegetation composition of Site A due to hen grazing. The bars represent the mean values of plant species identified by using the quadrat method, whereas the whiskers represent $95 \%$ confidence intervals $(* * * P<0.001)$.

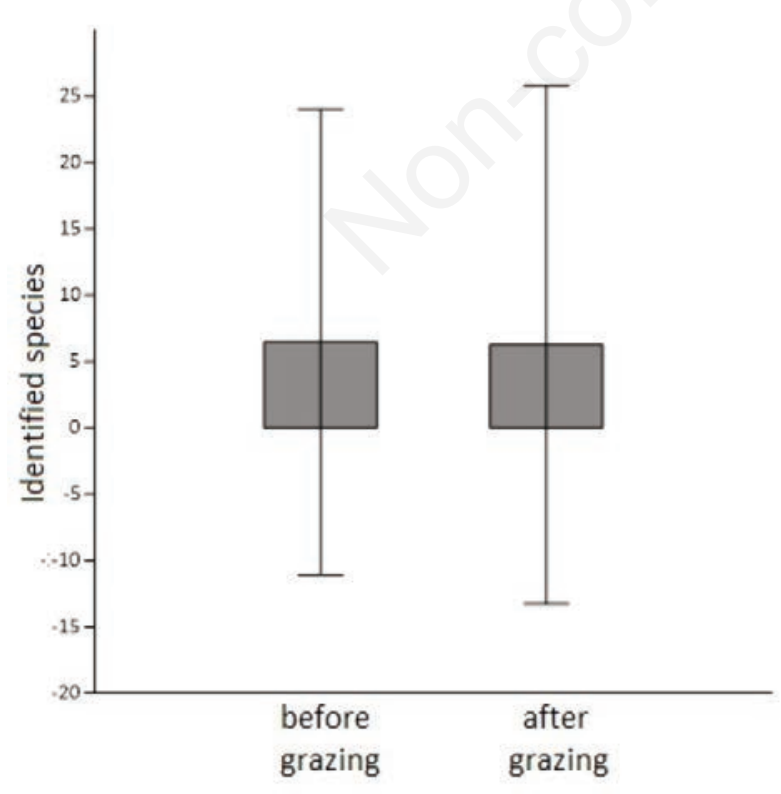

Figure 2. Changes in vegetation composition of Site B due to hen grazing. The bars represent the mean values of plant species identified by using the quadrat method, whereas the whiskers represent $95 \%$ confidence intervals.
Table 2. Relative percentage (\%) of plant species identified in Site $B$ before and after hen grazing.

\begin{tabular}{|c|c|c|}
\hline Species & Before grazing & After grazing \\
\hline Ajuga reptans & 0.53 & 0.83 \\
\hline Anagallis arvensis & 3.47 & 5.23 \\
\hline Anthemis arvensis & 0.27 & 0.00 \\
\hline Apium nodiflorum & 0.27 & 0.28 \\
\hline Arum italicum & 0.27 & 0.00 \\
\hline Avena sativa & 1.33 & 0.83 \\
\hline Bromus erectus & 2.40 & 1.10 \\
\hline Capsella bursa pastoris & 0.27 & 0.55 \\
\hline Cerastium arvensis & 1.33 & 0.00 \\
\hline Cichorium intybus & 2.40 & 0.55 \\
\hline Cirsium triumfetti & 0.53 & 2.48 \\
\hline Convolvulus arvensis & 0.80 & 1.38 \\
\hline Daucus carota & 2.67 & 2.20 \\
\hline Equisetum arvense & 4.27 & 5.51 \\
\hline Erigeron canadensis & 0.80 & 0.55 \\
\hline Eritrea centauris & 0.27 & 0.83 \\
\hline Geranium dissectum & 2.93 & 0.83 \\
\hline Geranium philicifolium & 1.07 & 0.00 \\
\hline Geranium rotundifolia & 0.00 & 0.55 \\
\hline Holcus lanatus & 0.53 & 0.00 \\
\hline Hordeum murinum & 0.27 & 0.00 \\
\hline Hypericum perforatum & 0.27 & 0.00 \\
\hline Lactuca serriola & 2.40 & 6.06 \\
\hline Lathyrus pratensis & 0.27 & 0.00 \\
\hline Linum multiflorum & 0.00 & 0.28 \\
\hline Lythrum salicaria & 0.27 & 0.00 \\
\hline Lolium perenne & 2.67 & 4.68 \\
\hline Lumex criscus & 0.00 & 1.38 \\
\hline Malva silvestris & 0.27 & 0.00 \\
\hline Matricaria romana & 0.00 & 0.28 \\
\hline Medicago hybridus & 1.60 & 3.31 \\
\hline Medicago truncatula & 3.73 & 2.20 \\
\hline Mentha longifolia & 1.07 & 3.03 \\
\hline Mentha suaveolens & 1.33 & 0.55 \\
\hline Papaver rhoeas & 1.07 & 0.28 \\
\hline Petasites hybridus & 0.27 & 0.00 \\
\hline Phalaris minor & 0.00 & 0.28 \\
\hline Phleum nodosum & 0.53 & 0.55 \\
\hline Helminthotheca echioides & 12.80 & 14.05 \\
\hline Picris hieracioides & 10.40 & 11.29 \\
\hline Plantago maior & 0.80 & 1.93 \\
\hline Poa annua & 1.87 & 0.00 \\
\hline Poa pratense & 3.73 & 2.48 \\
\hline Polygonum aviculare & 0.27 & 0.00 \\
\hline Potentilla reptans & 2.13 & 1.10 \\
\hline Rubus ulmifolius & 0.27 & 0.28 \\
\hline Rumex crispus & 1.33 & 0.55 \\
\hline Senecio vulgaris & 5.87 & 3.03 \\
\hline Sonchus oleraceus & 5.87 & 3.86 \\
\hline Trifolium campestris & 0.80 & 0.00 \\
\hline Trifolium pratense & 3.47 & 0.55 \\
\hline Trifolium repens & 3.73 & 6.34 \\
\hline Verbena officinalis & 2.40 & 6.06 \\
\hline Veronica anagallis aquatica & 0.27 & 0.28 \\
\hline Veronica arvensis & 0.80 & 1.10 \\
\hline Vicia cracca & 0.27 & 0.00 \\
\hline Vicia sativa & 0.27 & 0.00 \\
\hline \multirow[t]{2}{*}{ Dipsacus fullonum } & 0.27 & 0.55 \\
\hline & 100 & 100 \\
\hline
\end{tabular}


Table 3. Measures of alpha $($ mean \pm SD) diversity analysis in each site computed before and after hen grazing.

\begin{tabular}{lcccccc} 
Index & \multicolumn{3}{c}{ Site A } & Sign. & \multicolumn{2}{c}{ Site B } \\
& BF & AF & AF & Sign. \\
Species richness $(D)$ & $3.33 \pm 0.15$ & $2.75 \pm 0.08$ & $* * *$ & $2.99 \pm 0.08$ & $3.04 \pm 0.09$ & NS \\
Species diversity $(H)$ & $1.99 \pm 0.08$ & $1.73 \pm 0.05$ & $* *$ & $1.85 \pm 0.04$ & $1.87 \pm 0.05$ & NS \\
\hline Species evenness $(E)$ & $0.94 \pm 0.03$ & $1 \pm 0$ & NS & $1 \pm 0$ & $1 \pm 0$ & NS \\
\hline
\end{tabular}

$\mathrm{BF}$, before grazing; $\mathrm{AG}$, after grazing; Sign., significance. ${ }^{* *} \mathrm{P}<0.001 ;{ }^{* *} \mathrm{P}<0.01$; NS, not significant.

These results are mainly due to the aforementioned decrease in the number of taxa composing the herbaceous stratum of the site (from 46 to 30 ) and, to a lesser extent, to the change in the value of the relative percentage of some species. Conversely, the value of species evenness $(E)$ did not change significantly between the vegetation sampling periods. Concerning beta diversity analysis (Table 4), the value of the Morisita-Horn quantitative index $\left(C_{M H}\right)$ in site $\mathrm{A}$ was 0.874 , indicating that the degree of overlap between the two sampling periods was high. The Sørensen qualitative similarity index $\left(C_{s}\right)$ was 0.756 , as consequence of the high number of plant species shared by the two periods. Concerning site B, according the Student $t$-test, there were no significant differences in richness, diversity and evenness between the two periods (Table 3 ): these results seem to confirm that the control of turf growth by the hens was less severe than it was in site A. This seems to be also corroborated by both the Morisita-Horn and Sørensen indices: both the values $\left(C_{M H}=0.903 ; C_{s}=0.778\right.$; Table 4$)$ indicated a high overlap between the two vegetation sampling periods, and were also higher than those observed in site A. Overall, our results reflect those of Liu et al. (2013) who observed the maintenance of similar aboveground plant biomass under chicken grazing and the unstocked control.

\section{Egg composition}

The chemical composition of eggs from site A (group A) and B (group B) is shown in Tables 5 and 6, respectively. It is now well established from a variety of studies (Roberts, 2004; Ahmadi and Rahimi, 2011; Yang et al., 2014) that egg composition can be affected by several factors (e.g., age, breed, nutrition, type of rearing system, time of oviposition, etc.), which make direct comparison of results from different investigations difficult. In the present study, the values of some chemical parameters were broadly in line with previous studies (Basmacioğlu and Ergül, 2005; Matt et al., 2009; Krawczyk et al., 2009, 2011; Anderson, 2011; Küçüky1lmaz et al., 2012; Rizzi and Marangon, 2012). For example, there were similarities between the protein content of eggs from both sites and that reported by Krawczyk (2009) for backyard hens or Matt et al. (2009) and Küçükyılmaz et al. (2012) for caged hens. In contrast, our values were lower than those found in a study on the quality of organic eggs from hybrid and Italian breed hens (Rizzi and Marangon, 2012).

As shown in Tables 5 and 6 , the Student $t$-test showed significant differences between the eggs from both sites (group A and B) and those from control group for most of the chemical parameters. For example, eggs from group A and B had significant $(\mathrm{P}<0.001)$ lower carbohydrate, lipid and protein content than those from control group. The difference in cholesterol content between the eggs from both sites and those from control group was also statistically significant $(\mathrm{P}<0.001)$ : compared to control eggs, those from group A were richer in cholesterol, whereas eggs from group $\mathrm{B}$ were lower. Concerning fatty acid composition, the contents of saturated and polyunsaturated fatty acids were in significant higher
Table 4. Measures of beta diversity analysis in each site computed before and after hen grazing.

\begin{tabular}{lcc}
\hline Index & Site A & Site B \\
Morisita-Horn (CMH) & 0.874 & 0.903 \\
Sorensen (CS) & 0.756 & 0.778 \\
\hline
\end{tabular}

Table 5. Chemical composition of eggs laid by hens grazing in site $\mathrm{A}(\operatorname{mean} \pm \mathrm{SD})$.

\begin{tabular}{lccc} 
Parameter & Group A & Control group & Sign. \\
Carbohydrates, \% & $0.70 \pm 0.25$ & $1.01 \pm 0.24$ & $* * *$ \\
Proteins, \% & $12.41 \pm 0.51$ & $13.01 \pm 0.52$ & $* * *$ \\
\hline Lipids, \% & $9.50 \pm 0.51$ & $11.11 \pm 0.52$ & $* * *$ \\
Dry matter, \% & $18.74 \pm 0.51$ & $18.72 \pm 0.49$ & NS \\
\hline Ash, \% & $1.76 \pm 0.05$ & $1.11 \pm 0.05$ & $* * *$ \\
Monounsaturated fatty acids, \% & $4.38 \pm 0.05$ & $6.87 \pm 0.05$ & $* * *$ \\
\hline Polyunsaturated fatty acids, \% & $3.29 \pm 0.03$ & $2.76 \pm 0.05$ & $* * *$ \\
Saturated fatty acids, \% & $6.38 \pm 0.04$ & $5.39 \pm 0.04$ & $* * *$ \\
\hline Cholesterol, mg $/ \mathrm{g}$ & $353.58 \pm 3.37$ & $322.91 \pm 3.11$ & $* * *$ \\
Vitamin A, mg $100 \mathrm{~g}^{-1}$ & $0.32 \pm 0.04$ & $0.28 \pm 0.05$ & $* *$ \\
\hline Vitamin E, mg $100 \mathrm{~g}^{-1}$ & $5.40 \pm 0.04$ & $5.48 \pm 0.05$ & $* * *$ \\
Vitamin D, mg $100 \mathrm{~g}^{-1}$ & $0.60 \pm 0.08$ & $1.80 \pm 0.25$ & $* *$ \\
\hline Lysozyme, \% & $0.50 \pm 0.07$ & $0.49 \pm 0.06$ & NS \\
\hline Sign., significance. ${ }^{* * *}<<0.001 ; * * \mathrm{P}<0.01 ;$ NS, not significant. & &
\end{tabular}

Table 6. Chemical composition of eggs laid by hens grazing in site $B($ mean $\pm \mathrm{SD})$.

\begin{tabular}{lccc} 
Parameter & Group B & Control group & Sign. \\
Carbohydrates, \% & $0.71 \pm 0.25$ & $1.01 \pm 0.24$ & $* * *$ \\
Proteins, \% & $12.56 \pm 0.51$ & $13.01 \pm 0.52$ & $* * *$ \\
\hline Lipids, \% & $8.71 \pm 0.52$ & $11.11 \pm 0.52$ & $* * *$ \\
Dry matter, \% & $18.26 \pm 0.48$ & $18.72 \pm 0.49$ & $* * *$ \\
\hline Ash, \% & $1.60 \pm 0.05$ & $1.11 \pm 0.05$ & $* * *$ \\
Monounsaturated fatty acids, \% & $8.27 \pm 0.05$ & $6.87 \pm 0.05$ & $* * *$ \\
\hline Polyunsaturated fatty acids, \% & $3.07 \pm 0.04$ & $2.76 \pm 0.04$ & $* * *$ \\
Saturated fatty acids, \% & $9.86 \pm 0.03$ & $5.39 \pm 0.04$ & $* * *$ \\
\hline Cholesterol, mg/g & $295.58 \pm 3.37$ & $322.91 \pm 3.11$ & $* * *$ \\
Vitamin A, mg $100 \mathrm{~g}^{-1}$ & $0.23 \pm 0.04$ & $0.28 \pm 0.05$ & $* *$ \\
\hline Vitamin E, mg $100 \mathrm{~g}^{-1}$ & $5.42 \pm 0.04$ & $5.48 \pm 0.05$ & $* * *$ \\
Vitamin D, mg $100 \mathrm{~g}^{-1}$ & $1.00 \pm 0.09$ & $1.80 \pm 0.25$ & $* * *$ \\
\hline Lysozyme, \% & $0.48 \pm 0.05$ & $0.49 \pm 0.06$ & NS \\
\hline
\end{tabular}

Sign., significance. ${ }^{* * *} \mathrm{P}<0.001 ;{ }^{* *} \mathrm{P}<0.01$; NS, not significant. 
amount $(\mathrm{P}<0.001)$ in eggs from group A than in control eggs, which were instead characterised by the highest content of monounsaturated fatty acids. Results from site B showed that, the eggs from group B had the highest content of saturated, monounsaturated, and polyunsaturated fatty acids. With regard to vitamin content, compared with control hens, group A individuals produced eggs with the highest level of vitamin A and the lowest of vitamin E and D. Eggs from group B were characterised by the highest content of the aforementioned vitamins. There were no significant differences in lysozyme content between the eggs from both experimental groups and those from control group.

Studies correlating nutrition and rearing system with some chemical parameters of eggs have generally produced conflicting results. For instance, previous studies (Minelli et al., 2007; Matt et al., 2009) have shown that the cholesterol content was greater in organic eggs than in conventional ones. Conversely, Krawczyk et al. (2011) found a lower cholesterol content in eggs from free-range system. Other studies (Karsten et al., 2010; Anderson, 2011; Küçükyılmaz et al., 2012) found no difference in cholesterol content between the range- and cage-produced eggs. The same considerations apply with respect to the vitamin content of eggs recorded in the present study: in fact, Krawczyk et al. (2011) found a higher vitamin A concentration in free-range eggs, whereas Matt et al. (2009) reported that the concentration vitamin A was higher in conventional eggs. This corroborates the idea that, irrespective of management system, the vitamin content of eggs depends on the vitamin content of feed (Melluzzi et al., 2000; Leeson and Caston, 2003).

Based on the above evidences and given that the hens received the same feed, it can be stated that the observed differences between eggs from the two sites are mainly related to the variation in hen diet, depending on the local availability and abundance of different food resources in each site. This seems to be in accordance with previous research (Mohammed et al., 2013) which showed that, the crop content of the outdoor hens consisted, among others, of plant material, grit stones, snails and oyster shells, seeds, insects, worms, and larvae. After all, it has been suggested that fat content in freerange eggs can be increased by the consumption of forage, wild seeds and insects (Anderson, 2011). Krawczyk et al. (2011) reported that eating fresh plants and herbs from the free-range led to low egg levels of lipids and total cholesterol. According to the same authors, the increased levels of protein of free-range eggs associated with invertebrates and plants enriching the diets consumed by the hens. Similarly, insects, worms, and larvae, along with plant species composing the ground vegetation of each site, may also have played a role in the difference observed in egg composition.

\section{Conclusions}

It is well established that allowing hens to free-range in a pasture offer several advantages in terms of soil fertility, weed control, farm profitability, etc.. Integrating poultry into an orchard may offer the same advantages, thus resulting a promising tool for developing more sustainable farming systems. It is from this perspective that the present study, aimed at evaluating the impact of poultry integrated into hazelnut orchard, was carried out in two different sites. Our findings showed that the use of hens influenced the herbaceous stratum of the study sites; this variation in vegetation composition was measured by computing some univariate measures of alpha diversity. After grazing, species richness and diversity were lower in site A and higher in site B, but with the latter difference not being statistically significant. However, the observed values indicated more a control of vegetation growth by hens grazing than an impact on it, as confirmed by beta diversity analysis.

Concerning egg quality, compared to control eggs, those from both sites had significantly lower contents of carbohydrates, proteins, lipids, vitamin E and D. There were differences in fatty acids and vitamin A content: eggs from site A had a higher content of saturated and monounsaturated fatty acids and a higher content of vitamin A than control eggs. Eggs from site B were instead characterised by the highest content of saturated, monounsaturated and polyunsaturated fatty acids and the lowest content in vitamin A. These results seem to indicate that egg quality was influenced by the food resources (e.g., plants, wild seeds and insects) available in each site.

Overall, our findings, although limited because the study sites are different and not comparable, suggest that hens can be positively integrated into hazelnut orchards. However, further research might explore other aspects (soil fertility, dietary preferences, etc.) to fully understand the implications of poultry grazing in an orchard system.

\section{Highlights}

- The impact of an integrated poultry-hazelnut orchard system on herbaceous plant species diversity and on egg quality was evaluated.

- Hen grazing may benefit herbaceous ground cover biodiversity of the orchards.

- Egg quality may be affected by the food resources available in the orchards.

\section{References}

Ahmadi F, Rahimi F, 2011. Factors affecting quality and quantity of egg production in laying hens: a review. World Appl. Sci. J. $12: 372-84$

Anderson KE, 2011. Comparison of fatty acid, cholesterol, and vitamin $\mathrm{A}$ and $\mathrm{E}$ composition in eggs from hens housed in conventional cage and range production facilities. Poultry Sci. 90:1600-8

Antell S, Ciszuk P, 2006. Forage consumption of laying hens - the crop content as an indicator of feed intake and AME content of ingested forage. Arch. Geflugelkd. 70:154-60.

AOAC, 2006. Official Methods of Analysis, 18th ed. AOAC Press, Gaithersburg, MD, USA.

Basmacioğlu H, Ergül M, 2005. Research on the factors affecting cholesterol content and some other characteristics of eggs in laying hens the effects of genotype and rearing system. Turk. J. Vet. Anim. Sci. 29:157-64.

Berg C, 2002. Health and welfare in organic poultry production. Acta Vet. Scand. 43:S37-S45.

Bonham CD, 1989. Measurements for terrestrial vegetation. Wiley, New York, USA.

Buzas MA, Gibson TG, 1969. Species diversity: benthic foraminifera in western North Atlantic. Science. 163:72-5.

Chielo L, Pike T, Cooper J, 2016. Ranging behaviour of commercial free-range laying hens. Animals. 6:28.

Clark MS, Gage, SH, 1996. Effects of free-range chickens and geese on insect pests and weeds in an agroecosystem. Am. J. Alternative Agric. 11:39-47.

Folch J, Lees M, Stanley GHS, 1957. A simple method for the isolation and purification of total lipids from animals tissues. J. 
Biol. Chem. 226:497-509.

Freschi P, Fascetti S, Musto M, Mallia E, Blasi AC, Cosentino C, Paolino R, 2014. Diet of the Apennine hare in a Southern Italy Regional Park. Eur. J. Wildl. Res. 60:423-30.

Freschi P, Fascetti S, Musto M, Mallia E, Cosentino C, Paolino R, 2015a. Diet of the Italian hare (Lepus corsicanus) in a seminatural landscape of southern Italy. Mammalia. 79:51-9.

Freschi P, Fascetti S, Musto M, Cosentino C, Paolino R, Valentini $\mathrm{V}, 2016$. Seasonal variation in food habits of the Italian hare in a south Apennine semi-natural landscape. Ethol. Ecol. Evol. 28:148-62

Freschi P, Fascetti S, Riga F, Cosentino C, Rizzardini G, Musto M, 2017. Diet composition of the Italian roe deer (Capreolus capreolus italicus) (Mammalia: Cervidae) from two protected areas. Eur. Zool. J. 84:34-42.

Freschi P, Musto M, Paolino R, Cosentino C, 2015b. Highlights on a Natura 2000 Network Site. In: A. Vastola (ed.) The Sustainability of Agro-Food and Natural Resource Systems in the Mediterranean Basin. Springer, Cham., pp 271-8.

Glatz PC, Ru YJ, Miao ZH, Wyatt SK, Rodda, BJ, 2005. Integrating poultry into a crop and pasture farming system. Int. J. Poultry Sci. 4:187-91.

Holt PS, Davies RH, Dewulf J, Gast RK, Huwe JK, Jones DR, Waltman D, Willian KR, 2011. The impact of different housing systems on egg safety and quality. Poult. Sci. 90:251-62.

Horsted K, Hammershoj M, Hermansen JE, 2006. Short-term effects on productivity and egg quality in nutrient-restricted versus non-restricted organic layers with access to different forage crops. Acta Agric. Scand. A Anim. Sci. 56:42-54.

Horsted K, Hermansen JE, Hansen H, 2007. Botanical composition of herbage intake of free-range laying hens determined by microhistological analysis of faeces. Arch. Geflugelkd. 71:145-51.

Karsten HD, Patterson PH, Stout R, Crews G, 2010. Vitamins A, E and fatty acid composition of the eggs of caged hens and pastured hens. Renew. Agr. Food Syst. 25:45-54.

Krawczyk J, 2009. Quality of eggs from Polish native Greenleg Partridge chicken-hens maintained in organic vs. backyard production systems. Anim. Sci. Pap. Rep. 27:227-35.

Krawczyk J, Sokołowicz Z, Szymczyk B, 2011. Effect of housing system on cholesterol, vitamin and fatty acid content of yolk and physical characteristics of eggs from Polish native hens. Arch. Geflügelk. 75:151-7.

Küçükyılmaz K, Bozkurt M, Herken EN, Çınar M, Çatlı AU, Bintaş E, Çöven F, 2012. Effects of rearing systems on performance, egg characteristics and immune response in two layer hen genotype. Asian-Australas J Anim Sci. 25:559-68.

Labella C, Lelario F, Bufo SA, Musto M, Freschi P, Cosentino C, 2016. Optimisation and validation of a chromatographic method for quantification of lysozyme in jenny milk. J. Food Nutr. Res.Slov. 55:263-9.

Langton RW, 1982. Diet overlap between the Atlantic cod Gadus morhua, silver hake, Merluccius bilinearis and fifteen other northwest Atlantic finfish. Bull. U. S. A. 80:745-59.

Lavigne A, Dumbardon-Martial E, Lavigne C, 2012. Les volailles pour un contrôle biologique des adventices dans les vergers. Fruits. 67:341-51.

Leeson S, Caston LJ, 2003. Vitamin enrichment of eggs. J. Appl. Poult. Res. 12:24-6.

Liu HY, Ivarsson E, Jonsson L, Holm L, Lundh T, Lindberg JE, 2011. Growth performance, digestibility, and gut development of broiler chickens on diets with inclusion of chicory (Cichorium intybus L.). Poult Sci. 90:815-23.

Liu M, Wang B, Osborne CP, Jiang G, 2013. Chicken farming in grassland increases environmental sustainability and economic efficiency. PLoS One. 8:e53977.

Magurran AE, 2004. Measuring biological diversity. Blackwell Science, Oxford, UK.

Margalef R, 1958. Information theory in ecology. Gen. Syste. 3:3671.

Margalef R, 1972. Interpretation not strictly statistical of representation of biological entities in multifactorial space. Investig. Pesquera. 36:183-90.

Matt D, Veromann E, Luik A, 2009. Effect of housing systems on biochemical composition of chicken eggs. Agr. Res. 7:662-7.

Meluzzi A, Giordani G, Urrai GF, Sirri F, 1993. Livelli di colesterolo e composizione acidica dell'uovo commerciale di produzione italiana. pp 507-11 in Atti X Cong. ASPA.

Meng L, Mao P, Guo Q, Tian X, 2016. Evaluation of meat and egg traits of Beijing-you chickens rotationally grazing on chicory pasture in a chestnut forest. Braz. J.Poultry Sci. 18:1-6.

Minelli G, Sirri F, Folegatti E, Meluzzi A, Franchini A, 2007. Egg quality traits of laying hens reared in organic and conventional systems. Ital. J. Anim. Sci. 6:728-30.

Mohammed KAF, Sarmiento-Franco L, Santos-Ricalde R, SolorioSanchez JF, 2013. Egg production, egg quality and crop content of Rhode Island Red hens grazing on natural tropical vegetation. Trop. Anim. Health Prod. 45:367-72.

Morisita M, 1959. Measuring of interspecific association and similarity between communities. Mem. Fac. Sci. Kyushu Univ. Ser. E (Biol). 3:65-80.

Mugnai C, Dal Bosco A, Castellini C, 2009. Effect of rearing system and season on the performance and egg characteristics of Ancona laying hens. Ital. J. Anim. Sci. 8:175-88.

Paolotti L, Boggia A, Castellini C, Rocchi L, Rosati A, 2016. Combining livestock and tree crops to improve sustainability in agriculture: a case study using the Life Cycle Assessment (LCA) approach. J. Clean. Prod. 131:351-63.

Pignatti S, Guarino R, La Rosa M, 2019. Flora d'Italia. EdagricoleEdizioni Agricole di New Business Media srl, Milano, Italy.

Rizzardini G, Fascetti S, Pietri C, Riga F, Cosentino C, Freschi P, 2019. Feeding preferences in dry season of the Italian hare (Lepus corsicanus) in two sites of Corsica. Eur. J. Wildl. Res. 65:43.

Rizzi C, Marangon A, 2012. Quality of organic eggs of hybrid and Italian breed hens. Poultry Sci. 91:2330-40.

Roberts JR, 2004. Factors affecting egg internal quality and egg shell quality in laying hens. J. Poultry Sci. 41:161-77.

Rosati A, Boggia A, Castellini C, Paolotti L, Rocchi L, 2016. When chickens graze in olive orchards, the environmental impact of both chickens and rearing and olive growing decreases. pp 362364 in Book of abstract 3rd European Agroforestry Conference, Montpellier, France.

Shannon CE, Weaver W, 1949. The mathematical theory of communication. University of Illinois Press, Urbana, USA.

Singh M, Cowieson AJ, 2013. Range use and pasture consumption in free-range poultry production. Anim. Prod. Sci. 53:1202-8.

Sirri F, Zampiga M, Soglia F, Meluzzi A, Cavani C, Petracci M, 2018. Quality characterisation of eggs from Romagnola hens, an Italian local breed. Poultry Sci. 97:4131-6.

Skřivan M, Pickinpaugh SH, Pavlů V, Skřivanová E, Englmaierova M, 2015. A mobile system for rearing meat chickens on pasture. Czech J. Anim. Sci. 60:52-9.

Sørensen TA, 1948. A method of establishing groups of equal amplitude in plant sociology based on similarity of species content, and its application to analyses of the vegetation on Danish commons. K. Dan Vidensk. Selskab Biol. Skrift. 5:1-34. 
Sossidou EN, Dal Bosco A, Elson HA, Fontes CMGA, 2011. Pasture-based systems for poultry production: implications and perspectives. World Poultry Sci. J. 67:47-58.

Timmermans B, Bestman M, 2016. Quality of apple trees and apples in poultry free range areas. pp 420-423 in 3rd European Agroforestry Conference Montpellier, France.

Yang HM, Yang Z, Wang W, Wang ZY, Sun HN, Ju XJ, Qi XM,
2014: Effects of different housing systems on visceral organs, serum biochemical proportions, immune performance and egg quality of laying hens. Eur. Poult. Sci. 78:1-9.

Zheng M, Mao P, Tian X, Meng L, 2019. Growth performance, carcass characteristics, meat and egg quality, and intestinal microbiota in Beijing-you chicken on diets with inclusion of fresh chicory forage. Ital. J. Anim. Sci. 18:1310-20. 